\title{
Brain Natriuretic Peptide Improves Long-Term Functional Recovery after Acute CNS Injury in Mice
}

\author{
Michael L. James,,2 Haichen Wang, ${ }^{2}$ Talaignair Venkatraman, ${ }^{3}$ Pingping Song,,4 \\ Christopher D. Lascola, ${ }^{3,4}$ and Daniel T. Laskowitz ${ }^{1,2,4}$
}

\begin{abstract}
There is emerging evidence to suggest that brain natriuretic peptide (BNP) is elevated after acute brain injury, and that it may play an adaptive role in recovery through augmentation of cerebral blood flow (CBF). Through a series of experiments, we tested the hypothesis that the administration of BNP after different acute mechanisms of central nervous system (CNS) injury could improve functional recovery by improving CBF. C57 wild-type mice were exposed to either pneumatic-induced closed traumatic brain injury (TBI) or collagenase-induced intracerebral hemorrhage (ICH). After injury, either nesiritide (hBNP) $(8 \mu \mathrm{g} / \mathrm{kg})$ or normal saline were administered via tail vein injection at $30 \mathrm{~min}$ and $4 \mathrm{~h}$. The mice then underwent functional neurological testing via rotorod latency over the following 5 days and neurocognitive testing via Morris water maze testing on days 24-28. Cerebral blood flow (CBF) was assessed by laser Doppler from 25 to 90 min after injury. After ICH, mRNA polymerase chain reaction (PCR) and histochemical staining were performed during the acute injury phase $(<24 \mathrm{~h})$ to determine the effects on inflammation. Following TBI and ICH, administration of hBNP was associated with improved functional performance as assessed by rotorod and Morris water maze latencies $(p<0.01)$. CBF was increased $(p<0.05)$, and inflammatory markers (TNF- $\alpha$ and IL-6; $p<0.05)$, activated microglial (F4/80; $p<0.05$ ), and neuronal degeneration (Fluoro-Jade B; $p<0.05$ ) were reduced in mice receiving hBNP. hBNP improves neurological function in murine models of TBI and $\mathrm{ICH}$, and was associated with enhanced CBF and downregulation of neuroinflammatory responses. hBNP may represent a novel therapeutic strategy after acute CNS injury.
\end{abstract}

Key words: brain natriuretic peptide; cerebral blood flow; intracerebral hemorrhage; nesiritide; neuroinflammation; neuroprotection; traumatic brain injury

\section{Introduction}

B RAIN NATRIURETIC PEPTIDE (BNP) was first discovered in the porcine central nervous system (Sudoh et al., 1988) and has since been established to be a major determinant for prognosis in patients with myocardial injury and congestive heart failure (Mukoyama et al., 1991; Rubattu et al., 2008). BNP is believed to play an important role in the regulation of electrolytes and water balance through its natriuretic effects, and inhibition of the renin-angiotensin-aldosterone system with regulation of vasculature permeability. In addition, BNP inhibits the activity of the sympathetic nervous system by interacting with baroreflex control, thereby modulating sympathetic tone (Luchner and Schunkert, 2004). In particular, it appears that BNP may have sympatholytic effects, providing a major advantage in the setting of congestive heart failure (Kasama et al., 2004).
Recent evidence suggests that BNP may also play an adaptive role following acute brain injury. For example, BNP elevations have been described in a pre-clinical model of middle cerebral artery occlusion (Brosnan et al., 1999), and in clinical studies of traumatic brain injury (TBI) (Kirchhoff et al., 2006; Lu et al., 2008; Powner et al., 2007; Sviri et al., 2006), stroke (Di Angelantonio et al., 2007; Jensen et al., 2006; Laskowitz et al., 2009; Modrego et al., 2008; Montaner et al., 2008; Nakagawa et al., 2005), and subarachnoid hemorrhage (McGirt et al., 2004). Although the role of BNP following brain injury remains unclear, potential beneficial effects may be related to its anti-inflammatory and vasoactive properties.

In this study we test the hypothesis that BNP may play a neuroprotective role by administering nesiritide, a recombinant form of naturally-occurring B-type human natriuretic peptide, in murine models of intracranial hemorrhage (ICH) and TBI, and assessing vestibulomotor and neurocognitive

${ }^{1}$ Department of Anesthesiology, ${ }^{2}$ Department of Medicine (Neurology), ${ }^{3}$ Department of Radiology, and ${ }^{4}$ Department of Neurobiology, Duke University Medical Center, Durham, North Carolina. 
performance after injury. Given the known effects of BNP on blood flow and inflammation, we evaluated whether functional effects were associated with improved post-injury cerebral blood flow (CBF) and/or reduced neuroinflammatory responses.

\section{Methods}

\section{Experimental design and matrix}

We evaluated the effects of nesiritide treatment after two separate brain injury models: closed head injury and ICH. Several cohorts of animals were utilized in each injury model. For both models we determined functional outcomes via rotorod and Morris water maze (MWM) testing. After TBI, we evaluated $\mathrm{CBF}$ by laser doppler and changes in serum sodium in the acute phase of injury. After ICH, we evaluated the CNS inflammatory response by mRNA polymerase chain reaction (PCR) and magnetic resonance imaging, microglial recruitment and activation by F4/80 staining, and neuronal degeneration by Fluoro-Jade B staining in the subacute phase of the injury. The experimental matrix is shown in Figure 1.

\section{Traumatic brain injury model}

Our murine injury model (Lynch et al., 2005) was adapted from a previously described model of closed cranial trauma for the rat (Foda and Marmarou, 1994). Male 10- to 12-weekold C57BL/6J mice (Jackson Laboratory, Bar Harbor, ME) were used in these experiments. Prior to injury, the mice were randomized to treatment or vehicle groups. The trachea was intubated after anesthesia induction with $4.6 \%$ isoflurane, and the lungs were mechanically ventilated with $1.6 \%$ isoflurane in $30 \%$ oxygen $/ 70 \%$ nitrogen. Rectal temperature was maintained at $37 \pm 0.2^{\circ} \mathrm{C}$. The animal was positioned in a stereotactic device, the scalp was incised, and the skull exposed. A concave 3-mm metallic disc was glued to the skull immediately caudal to the bregma. A 2.0-mm-diameter pneumatic impactor (Air-Power, Inc. High Point, NC) was used to deliver a single midline impact to the disc surface. The impactor was discharged at $6.8 \pm 0.2 \mathrm{~m} / \mathrm{sec}$ with a head displacement of $3 \mathrm{~mm}$. After impact, the animals were allowed to recover spontaneous ventilation, and were then extubated and given free access to food and water.

\section{Intracerebral hemorrhage model}

Our murine injury model (James et al., 2008b) was adapted from a previously described model of ICH in rats (Rosenberg et al., 1990). Male 10- to 12-week-old C57BL/6J mice (Jackson Laboratory) were used in these experiments to avoid potential effects of age-related vasculopathy. Prior to injury, the mice were randomized to treatment or vehicle groups. The trachea was intubated after anesthesia induction with $4.6 \%$ isoflurane and the lungs were mechanically ventilated with $1.6 \%$ isoflurane in $30 \%$ oxygen $/ 70 \%$ nitrogen. Rectal temperature was maintained at $37 \pm 0.2^{\circ} \mathrm{C}$ by an underbody warming system. The animal's head was secured in a stereotactic frame, local anesthetic was injected, and the scalp incised. After exposure of the skull, a burr hole was created $2 \mathrm{~mm}$ left lateral to the bregma, and a 0.5-mL syringe needle (Hamilton, Reno, NV) was advanced to a depth of $3 \mathrm{~mm}$ from the cortex. Type IV-S clostridial collagenase (Sigma, St. Louis, MO) was injected over $5 \mathrm{~min}$ ( $0.1 \mathrm{U}$ in $0.4 \mathrm{~mL} \mathrm{NS}$ ). The incision was then closed and the animals were allowed to recover spontaneous ventilation, after which they were extubated and given free access to food and water.

\section{Nesiritide administration}

Prior to injury, mice were randomized to receive low-dose nesiritide $(2 \mathrm{mg} / \mathrm{kg})$, high-dose nesiritide $(8 \mathrm{mg} / \mathrm{kg})$, or vehicle (sterile saline) via tail vein injection at $30 \mathrm{~min}$ and $4 \mathrm{~h}$. Drug and vehicle were administered in a volume of $100 \mathrm{~mL}$ sterile normal saline.

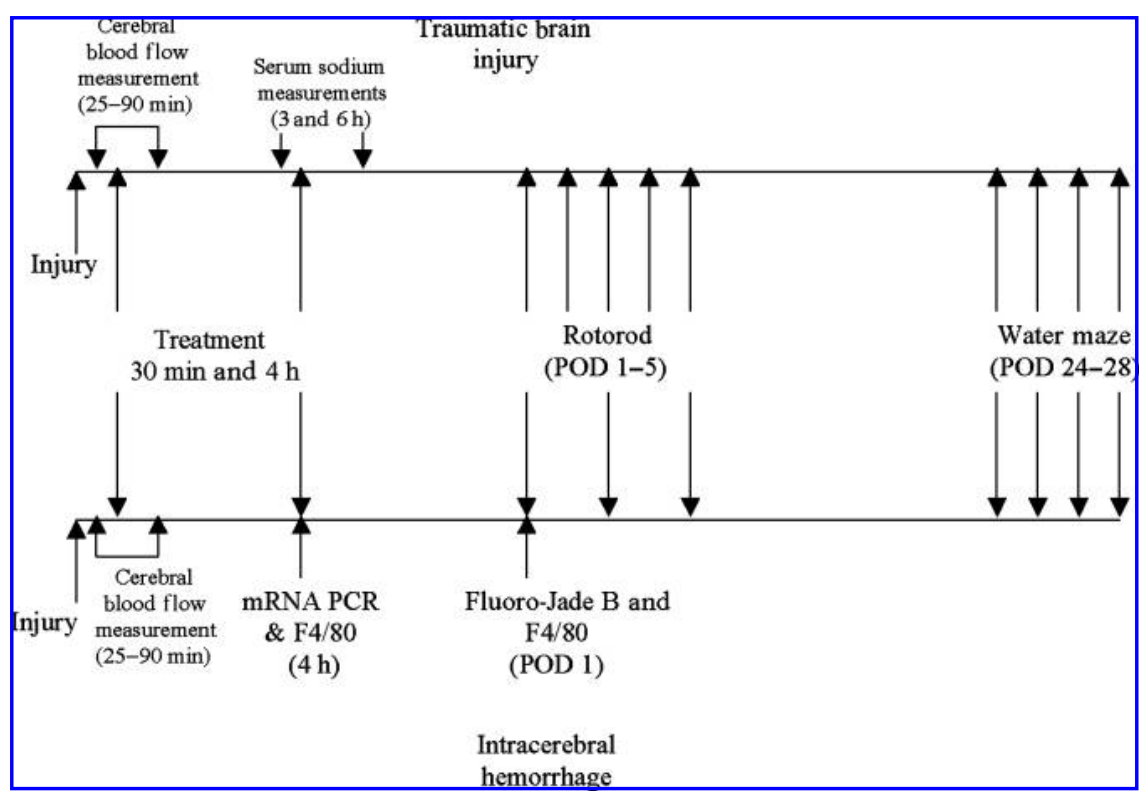

FIG. 1. Experimental matrix detailing the timing of outcome measures in each model (POD, postoperative day; PCR, polymerase chain reaction). 


\section{Neurological testing}

An automated rotorod (Ugo Basile, Comerio, Italy) was used to assess the effects of therapeutic intervention on vestibulomotor function (Hamm et al., 1994) On the day prior to injury, the mice underwent two consecutive conditioning trials at a set rotational speed (16 revolutions/min) for $60 \mathrm{sec}$, followed by three additional trials with accelerating rotational speeds. The average time to fall from the rotating cylinder in the latter three trials was recorded as baseline latency. After injury, the mice underwent consecutive daily testing with three trials of accelerating rotational speed (inter-trial interval of $15 \mathrm{~min}$ ). Average latency to fall from the rod was recorded. Mice unable to grasp the rotating rod were given a latency of $0 \mathrm{sec}$.

\section{Morris water maze testing}

The MWM (Morris 1984) was used to assess the effects of therapeutic intervention on spatial learning and memory. After injury, performance was evaluated in a black aluminum pool $(105 \mathrm{~cm}$ in diameter, $60 \mathrm{~cm}$ in depth) filled with water opacified with powdered milk. The pool contained a platform ( $7.5 \mathrm{~cm}$ in diameter) submerged $1 \mathrm{~cm}$ below the water's surface $\left(25-27^{\circ} \mathrm{C}\right)$. The maze was kept in a room dedicated to behavioral testing with light and sound maintained constant throughout training and testing. Prior to injury, the mice were trained on the visible platform ( $1 \mathrm{~d}$; the platform was flagged, located in a different quadrant for each trial to minimize quadrant habituation, and no extra-maze visual cues), and the hidden platform ( $4 \mathrm{~d}$; the platform was submerged in the western quadrant for all trials, with several extra-maze visual cues) versions of the MWM task to habituate the mice to handling and to swimming, as well as to teach them the goal of the task, which was to escape from the water by climbing onto a platform. Such habituation and pre-training has been shown to decrease stress, which negatively impacts the performance of mice on the MWM task (Holscher, 1999). Pre- and post-injury testing followed the same protocol. Each testing day consisted of four trials per day with an inter-trial interval of 20-30 min. For each trial, the mice were placed into the pool facing the perimeter and were allowed to search for the platform for a maximum of $90 \mathrm{sec}$. If they were unable to locate the platform within the allotted time, they were guided to it and remained on the platform for $10 \mathrm{sec}$ before being returned to their heated home cages. The mice were started in one of four different quadrants for each trial, with starting quadrants randomly defined each day. Latency to find the platform and swimming speed were recorded by a computerized video tracking system (KeilSoft LLC, Chapel Hill, NC).

On the final day of hidden platform testing, a probe trial was conducted to evaluate retention capabilities. The escape platform was removed from the pool and the mouse was released into the maze at a point diagonally opposite from the previous location of the platform (i.e., the eastern quadrant). The time spent searching all four and the number of crossings into the western quadrant was recorded. Post-injury MWM visible testing was conducted on day 23 , and hidden platform testing was conducted daily from day 24 through day 27 , with a probe trial following the last trial on day 28. Water maze testing was performed by an examiner blinded to treatment assignment.

\section{Measurement of serum sodium}

The effect of therapeutic intervention on serum sodium levels was assessed in a separate cohort of animals receiving either nesiritide or saline via tail vein injection at $30 \mathrm{~min}$ after TBI ( $n=4$ animals/group). As previously described, the mice were anesthetized, injured, and treated, after which a $0.2-\mathrm{mL}$ blood sample obtained via left ventricle puncture and analyzed with an IL GEM Premier 3000 blood gas analyzer (Global Medical Instrumentation, Ramsey, MI) at $3 \mathrm{~h}$ after TBI to assess blood gases and electrolytes.

\section{Laser doppler cerebral blood flow}

The effect of therapeutic intervention on CBF was assessed by laser doppler flowmetry in a separate cohort of animals receiving either nesiritide or saline via tail vein injection at $30 \mathrm{~min}$ after TBI ( $n=8$ animals/group). As previously described, the mice were anesthetized, injured, and treated, after which a 1.9-mm-diameter laser doppler needle probe was placed on the skull in the left middle cerebral artery distribution $(1 \mathrm{~mm}$ posterior and $5 \mathrm{~mm}$ lateral to the bregma). (Tsuchiya et al., 2003). Cortical perfusion values were recorded from 25$90 \mathrm{~min}$ after injury.

\section{Magnetic resonance imaging}

The effect of therapeutic intervention on $\mathrm{ICH}$ volume was assessed by magnetic resonance imaging (MRI) in a separate cohort of animals receiving either nesiritideor saline via tailvein injection at $30 \mathrm{~min}$ and $4 \mathrm{~h}$ after ICH ( $n=6$ animals/group). MRI was performed using a 7T Bruker MRI (Bruker Biospin, Newark, DE) at $4 \mathrm{~h}$ after injury. The animals were anesthetized via inhalation of $1.5 \%$ isoflurane in room air and cardiopulmonary parameters were monitored continuously. Core temperature was maintained at $37 \pm 0.5^{\circ} \mathrm{C}$ via a circulating water bath. Each MRI session lasted $20 \mathrm{~min}$, which was equivalent across all animal groups. Images were acquired at a 256- $\times-256$ matrix and a $4-\mathrm{cm}^{2}$ field of view. A RARE sequence was performed for both T1-weighted (TE/TR = 7.5/1300) and T2-weighted (TE/TR 12/4200) imaging. Eighteen slices of $1 \mathrm{~mm}$ thickness were performed for entire brain coverage. As previously described (James et al., 2008a), ICH volume measurements by MRI volumetric assessment and hematoxylin and eosin staining are strongly correlative.

\section{Quantitative real-time polymerase chain reaction}

To assess the effects of therapeutic intervention on early inflammation, q-PCR was performed for mRNA of inflammatory mediators. The mice were anesthetized, euthanized, and perfused with $30 \mathrm{~mL}$ PBS via transcardiac puncture at $4 \mathrm{~h}$ after ICH. The brains were sectioned mid-sagittally, flash frozen at $-20^{\circ} \mathrm{C}$, and stored at $-80^{\circ} \mathrm{C}$. RNA was extracted from pulverized frozen hemispheres using the PerfectPure RNA Tissue Kit (5 PRIME, Gaithersburg, MD), quantified using a Bio-Rad SmartSpec 3000 Spectrophotometer (Bio-Rad, Hercules, CA), and reverse transcribed to cDNA using the High Capacity cDNA Archive Kit (Applied Biosystems, Foster City, CA) with MultiScribe reverse transcriptase and random primers. The levels of mRNA expression were determined with an ABI 7300 Sequence Detection Software system (Applied Biosystems), using $100 \mathrm{ng}$ cDNA per reaction, adding Taqman Universal PCR master mix and TaqMan Assays-on-Demand 
Gene Expression primer/probe sets (all from Applied Biosystems) for the murine cytokines. Relative mRNA quantification was calculated using the $2^{-\Delta C}$ method (Livak and Schmittgen, 2001). The threshold cycle number (Ct) of the target gene for each sample was normalized using a housekeeping gene (endogenous 18S), and calibrated to the control samples (uninjured animals). Final results were expressed as fold changes over uninjured animals.

\section{Immunohistochemistry: Fluoro-Jade B staining and $F 4 / 80$ staining}

To assess the effects of therapeutic intervention on early inflammation, immunohistochemical staining was performed for Fluoro-Jade B (Schmued and Hopkins, 2000) (a marker of degenerating neurons), and F4/80 (a marker for microglia), after ICH. The mice were anesthetized, euthanized, and perfused with $30 \mathrm{~mL}$ PBS via transcardiac puncture at either $4 \mathrm{~h}$ or $24 \mathrm{~h}$ after ICH. Sagittal sections $(40 \mu \mathrm{m})$ were cut on a vibratome and collected in cryoprotectant solution containing ethylene glycol, sucrose, and sodium phosphate. Every eighth section was mounted onto a charged slide.

For assessment of neuronal degeneration, the slides were stained with Fluoro-Jade B and immersed in 100\% ethanol for $3 \mathrm{~min}$, followed by $1 \mathrm{~min}$ in $70 \%$ ethanol, and $1 \mathrm{~min}$ in distilled water. The slides were then transferred to a solution of $0.06 \%$ potassium permanganate for $15 \mathrm{~min}$, followed by a 1-min rinse in distilled water. The slides were then stained in $0.001 \%$ Fluoro-Jade B solution (Histochem, Jefferson, AR) prepared in $0.1 \%$ acetic acid for $30 \mathrm{~min}$, and the slides were rinsed for $1 \mathrm{~min}$ in distilled water three times. The slides were then dried overnight in the dark. The following day, the slides were cleared by immersion in xylene and cover-slipped with DPX (Fluka, Milwaukee, WI).

For microglia staining, F4/80 immunohistochemistry was performed on brains prepared and cut as described above. Free-floating sections were incubated in $1 \% \mathrm{H}_{2} \mathrm{O}_{2}$ for $5 \mathrm{~min}$, then transferred to $0.1 \%$ saponin for $1 \mathrm{~h}$. Next the sections were incubated for $30 \mathrm{~min}$ in $10 \%$ goat serum, followed by two successive blocking steps with avidin and biotin for 15 min each. Monoclonal rat anti-mouse F4/80 (MCA497R; Serotec, Raleigh, NC) was applied overnight at $40^{\circ} \mathrm{C}$ at a dilution of 1:10,000. After washing with PBS, biotinylated goat anti-rat IgG secondary antibody (1:333; Vector Laboratories, Inc., Burlingame, CA) was applied for $20 \mathrm{~min}$, followed by avidin-biotin-peroxidase complex treatment for $12 \mathrm{~min}$ (ABC kit; Vector Laboratories, Inc.). Staining was visualized with diaminobenzidine (DAB; Vector Laboratories, Inc.). The sections were mounted onto slides and allowed to dry overnight. Following immunostaining, all sections were counterstained with hematoxylin (Fisher Scientific, Fair Lawn, NJ) for $4 \mathrm{~min}$. After dehydration the sections were cover-slipped using DPX.

\section{Stereological analysis}

Cell counting was conducted using a Nikon 218912 light microscope interfaced with the StereoInvestigator software package (MicroBrightField, Williston, VT). The number of stained cells per volume of hippocampus was estimated using the optical fractionator method (West et al., 1991, 1996). The optical fractionator is an unbiased counting method, which is independent of the size, shape, and orientation of the cells to be counted. The parameters of the fractionator-sampling scheme were established in a pilot experiment and were uniformly applied to all animals. Before counting, all slides were coded to avoid experimenter bias. As determined by StereoInvestigator, we chose three sagittal sections $(40 \mu \mathrm{m})$ spaced eight sections apart along the hippocampal formation by systematic random sampling. This number of sections proved sufficient to provide a coefficient of error of $0.09-0.11$. The sections that contained both caudate, putamen, and only one part of the hippocampus were selected for counting. On each section the whole hippocampal area was delineated. The sampling grid was $521.1(x) \times 355.7(y) \mu \mathrm{m}$. Cells were counted within a probe volume defined by the counting frame $(80 \times 80 \mu \mathrm{m})$ and the dissector height $(11 \mu \mathrm{m})$. Only cells within the counting frame or overlapping the right or superior border of the counting frame, and for which nuclei came into focus while focusing down through the dissector height, were counted. The total number of F4/80- or Fluoro-Jade Bimmunopositive microglia was calculated per hippocampal volume of $640-\mu \mathrm{m}$ thickness.

\section{Statistical analysis}

Rotorod performance and MWM latencies were compared with two-way repeated-measures analysis of variance with day as the repeated variable. The $F$ values were calculated, and if the probability distribution of $F$ with the appropriate degrees of freedom suggested a significant group effect, pairwisetesting was performed between groupsusing Scheffe's post-hoc method to correct for multiple comparisons. The numbers of Fluoro-Jade and F4/80 cell counts were compared between groups using the Mann-Whitney $U$ statistic. Statistical significance was set at $p<0.05$. All values were expressed as mean \pm standard error of the mean (SEM) and were performed using JMP software (v7.0.1; SAS Institute Inc., Cary, NC).

\section{Results}

\section{Nesiritide improves functional outcome after brain injury}

Mice received saline, low-dose, or high-dose nesiritide $(8 \mu \mathrm{g} / \mathrm{kg} ; n=8 /$ group) after TBI. Testing of vestibulomotor function as assessed by rotorod latency demonstrated that high-dose nesiritide administration provided a durable improvement in functional outcomes over the 5 days tested. This effect was dose-dependent, as high-dose nesiritide was associated with significantly better rotorod performance than saline- or low-dose-treated animals ( $p<0.001$; Fig. 2).

We next extended our results to a murine model of $\mathrm{ICH}$ by randomizing mice to receive either saline or nesiritide $(8 \mu \mathrm{g} / \mathrm{kg})$ via tail vein injection at $30 \mathrm{~min}$ and $4 \mathrm{~h}$ ( $n=8 /$ group) after injury. Testing of vestibulomotor function as assessed by rotorod latency demonstrated that nesiritide administration provided a durable improvement in functional outcomes over the 5 days tested ( $p<0.01$; Fig. 3 ) compared to mice receiving saline. This effect does not appear related to hemorrhage volume, as MRI at $4 \mathrm{~h}$ post-injury did not reveal any difference in lesion volume $\left(25.0 \pm 0.5\right.$ versus $21.0 \pm 0.3 \mathrm{~mm}^{3}$ for $\mathrm{ICH}+\mathrm{BNP}$ versus $\mathrm{ICH}+$ saline, respectively; $n=5$ /group; Fig. 4). Thus our data suggest that administration of nesiritide had beneficial effects across several independent paradigms of brain injury. 


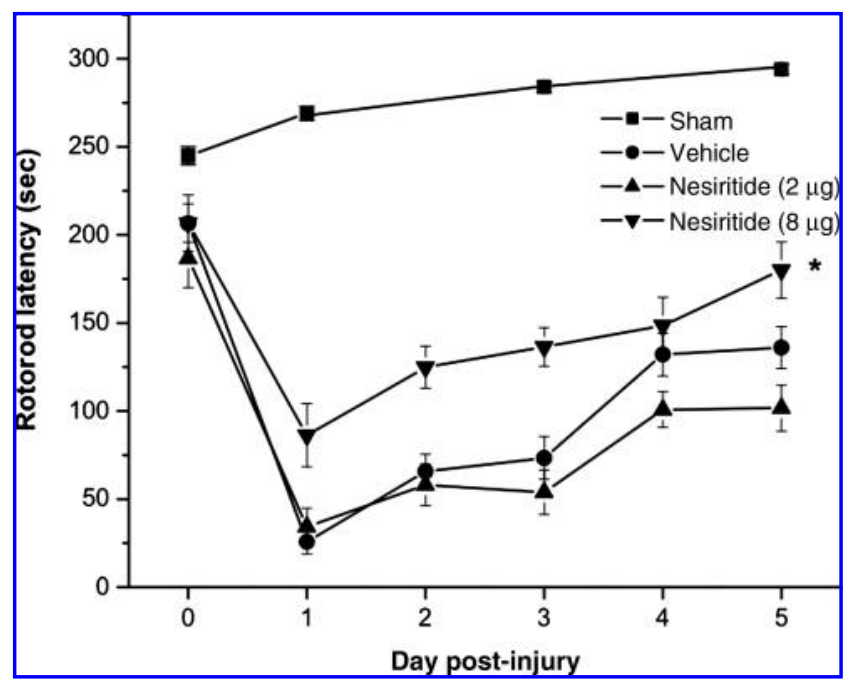

FIG. 2. Rotorod latencies over consecutive days after traumatic brain injury (TBI) in mice given nesiritide $(2 \mu \mathrm{g} / \mathrm{kg}$ [upward-pointing triangles] or $8 \mu \mathrm{g} / \mathrm{kg}$ [downward-pointing triangles]) or saline by tail vein injection $30 \mathrm{~min}$ and $4 \mathrm{~h}$ after injury. Mice given $8 \mu \mathrm{g} / \mathrm{kg}$ nesiritide demonstrated significantly longer latencies over the 5 days of testing $\left({ }^{*} p<0.05\right.$ nesiritide versus saline).

One possible explanation for the beneficial effects of nesiritide was that treatment was associated with a reduction in intracranial hypertension due to its natriuretic effects. To address this possibility, a separate cohort of mice was subjected to TBI ( $n=5 /$ group) and randomized to receive either saline or nesiritide $(8 \mu \mathrm{g} / \mathrm{kg})$ via tail vein injection at $30 \mathrm{~min}$ and $4 \mathrm{~h}$ after injury. Due to the short half-life of nesiritide, serum sodium was measured at 3 and $6 \mathrm{~h}$ in both groups and found to be similar at both time points ( $3 \mathrm{~h}$ : $144.6 \pm$ $0.7 \mathrm{mmol} / \mathrm{L}$ versus $145 \pm 0.7 \mathrm{mmol} / \mathrm{L}$ for $\mathrm{TBI}+$ saline ver-

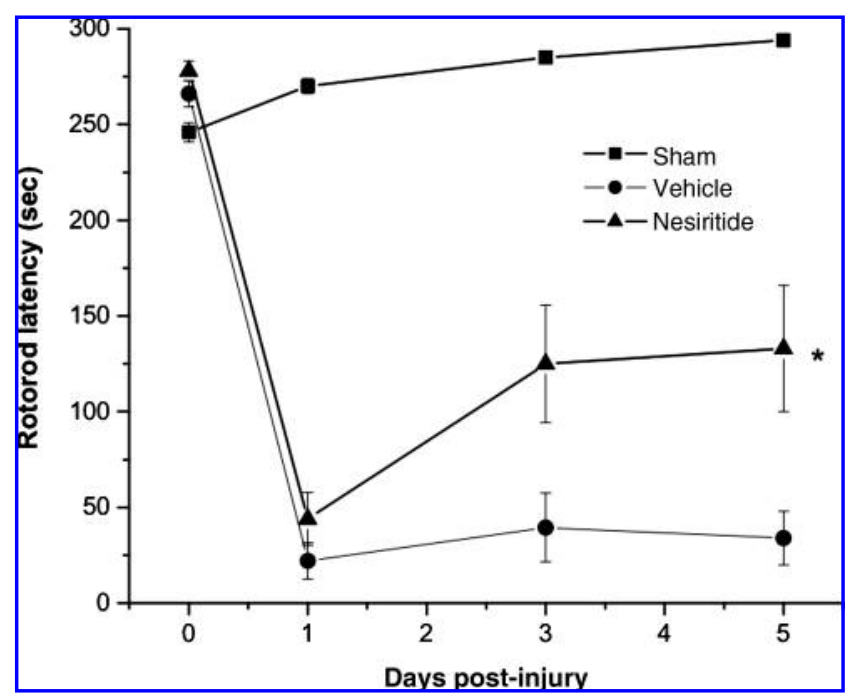

FIG. 3. Rotorod latencies over consecutive days after intracerebral hemorrhage in mice given nesiritide $(8 \mu \mathrm{g} / \mathrm{kg})$ or saline by tail vein injection at $30 \mathrm{~min}$ and $4 \mathrm{~h}$ after injury. Mice given nesiritide demonstrated significantly longer latencies over the 7 days of testing $\left({ }^{*} p<0.05\right.$ nesiritide versus saline). ne versus $\mathrm{TBI}+\mathrm{BNP}$, respectively; $6 \mathrm{~h}: 144.6 \pm 0.7 \mathrm{mmol} / \mathrm{L}$ versus $145 \pm 0.7 \mathrm{mmol} / \mathrm{L}$ for $\mathrm{TBI}+$ saline versus $\mathrm{TBI}+\mathrm{BNP}$, respectively). In separate cohorts, daily weights were assessed in mice subjected to TBI or ICH ( $n=8$ /group) after the administration of saline or nesiritide $(8 \mu \mathrm{g} / \mathrm{kg})$ via tail vein injection $30 \mathrm{~min}$ and $4 \mathrm{~h}$ after injury. No difference in weight over the 7 days measured was demonstrated between the control and nesiritide-treated animals in either type of injury, suggesting that the beneficial effects of nesiritide extend beyond its natriuretic action.

\section{Determination of long-term functional effects}

To verify that these short-term functional improvements were sustained, we performed MWM testing in C57 mice randomized to receive saline or nesiritide $(8 \mu \mathrm{g} / \mathrm{kg})$ via tail vein injection at $30 \mathrm{~min}$ and $4 \mathrm{~h}$ after injury by TBI or ICH ( $n=12$ /group). Nesiritide administration resulted in shortened platform-finding latencies over the 4 days tested, in both mice injured via TBI and ICH ( $p<0.05$ in both groups; Fig. 5) compared to mice injured via the same mechanism but treated with saline. These data suggest that treatment with nesiritide was associated with a long-term benefit in neurocognitive function.

\section{Effects of nesiritide on cerebral blood flow}

To determine the extent to which the neuroprotective effects of nesiritide are due to augmentation of CBF after acute CNS injury, laser doppler blood flow studies were performed in mice after injury with TBI or ICH following administration of saline or nesiritide $(8 \mu \mathrm{g} / \mathrm{kg})$. We have previously demonstrated that despite the dynamic range of cerebral blood flow seen immediately following injury, there is universal hypoperfusion by $20 \mathrm{~min}$ (Wang et al., 2007b); therefore we chose to begin monitoring via laser doppler at $25 \mathrm{~min}$ after injury. In the ICH paradigm ( $n=5$ /group), although CBF was markedly depressed in the injured hemisphere, no difference in laser doppler flow was measured at either $30 \mathrm{~min}$ or $4 \mathrm{~h}$ after injury. However, nesiritide treatment was associated with a significant augmentation of CBF after injury in the TBI animals, although this effect was not noted at $4 \mathrm{~h}(n=5 /$ group; $92.7 \pm 17.2 \%$ versus $48.7 \pm 12.6 \%$ change for $\mathrm{TBI}+\mathrm{BNP}$ versus $\mathrm{TBI}+$ saline, respectively; $p<0.05$; Fig. 6).

\section{Nesiritide reduces central nervous system inflammation}

As glial activation and neuroinflammatory responses may exacerbate the development of cerebral edema and secondary brain injury, we next sought to determine whether nesiritide was exerting immunomodulatory effects on the CNS. Quantitative mRNA PCR was performed following ICH for inflammatory cytokines in mice that received nesiritide $(8 \mu \mathrm{g} / \mathrm{kg})$ or saline injection at $30 \mathrm{~min}$ and $4 \mathrm{~h}$ after injury ( $n=5$ /group). Although endothelium-derived nitric oxide (eNOS) mRNA levels were no different between groups, TNF$\alpha$ and IL- 6 mRNA were significantly reduced at $4 \mathrm{~h}$ post-injury in the ipsilateral hemispheres of mice receiving nesiritide (TNF- $\alpha$ : 3.86 versus $76.78 \pm 18.99$ fold change for $\mathrm{ICH}+\mathrm{BNP}$ versus ICH + saline, respectively $[p<0.01]$; IL-6: $10.95 \pm 1.99$ versus $42.29 \pm 15.26$ fold change for $\mathrm{ICH}+\mathrm{BNP}$ versus $\mathrm{ICH}+$ saline, respectively [ $p<0.05]$; Fig. 7). 

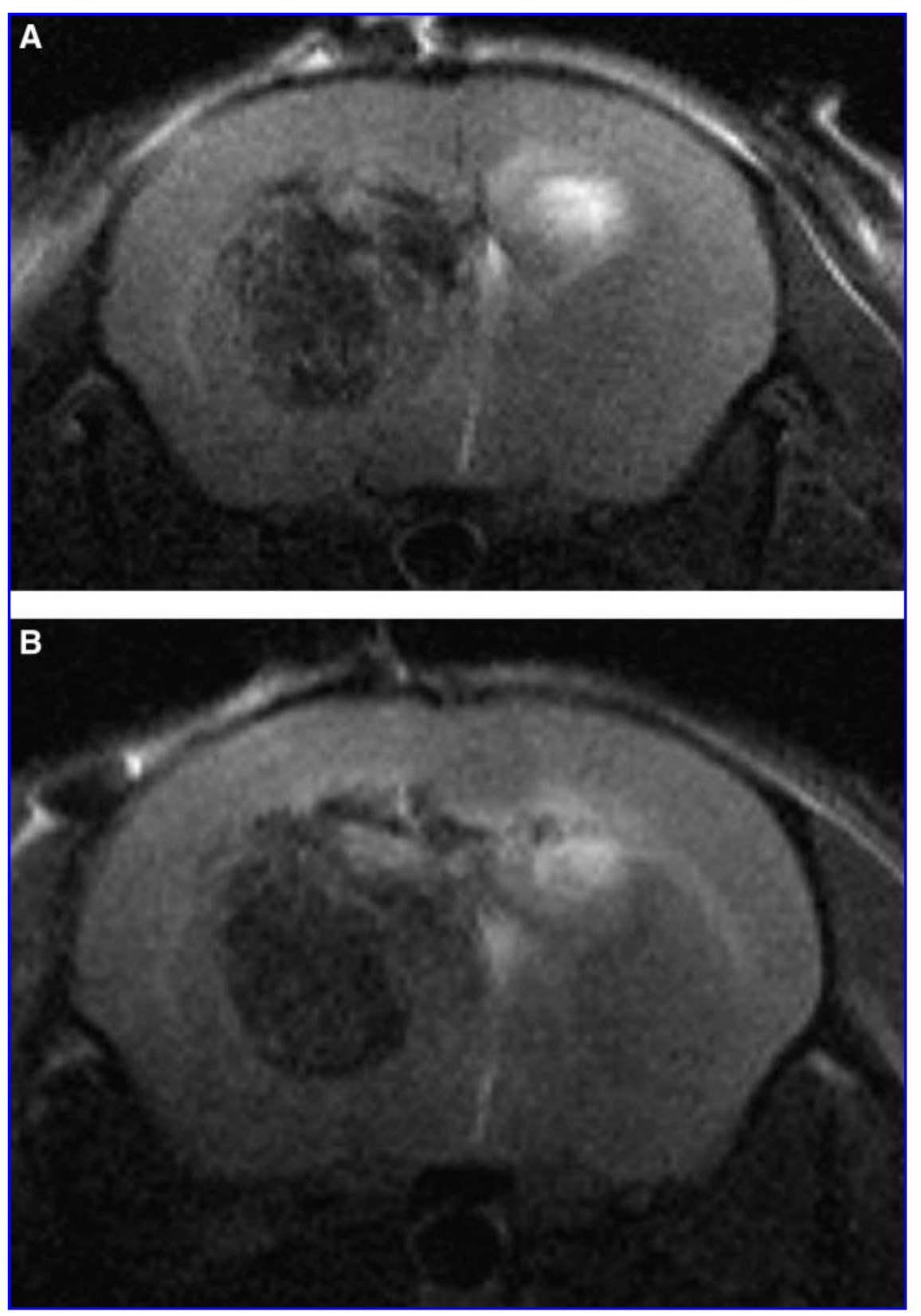

FIG. 4. Magnetic resonance images demonstrating similar hemorrhage volumes $4 \mathrm{~h}$ after intracerebral hemorrhage in mice given nesiritide $(8 \mu \mathrm{g} / \mathrm{kg} ; \mathbf{A})$ or saline (B) by tail vein injection at $30 \mathrm{~min}$ and $4 \mathrm{~h}$ after injury. Though nesiritide increases cerebral blood flow, it does not increase hemorrhage volume.

To determine if the upregulation of inflammatory cytokines was related to an increase in microglial activation, we performed immunohistochemistry with F4/80 staining, which identifies cells of macrophage lineage such as microglia, after $\mathrm{ICH}$ in the hippocampi of mice that received nesiritide $(8 \mu \mathrm{g} / \mathrm{kg})$ or saline injection $30 \mathrm{~min}$ and $4 \mathrm{~h}$ after injury ( $n=6 /$ group/time point). At $4 \mathrm{~h}$ post-injury the number of cells staining positive for F4/80 were similar in the contralateral hippocampi, but reduced in the ipsilateral hippocampi of mice receiving nesiritide (ipsilateral hippocampus: $5.53 \pm 0.53$ versus $7.89 \pm 0.26$ cells $/ 10^{6} \mathrm{~mm}^{3}$ for $\mathrm{ICH}+\mathrm{BNP}$ versus $\mathrm{ICH}+$ saline, respectively $[p<0.05]$; contralateral hippocampus: $3.60 \pm 0.79$ versus $4.68 \pm 0.65$ cells $/ 10^{6} \mathrm{~mm}^{3}$ for $\mathrm{ICH}+\mathrm{BNP}$ versus ICH + saline, respectively). The number of cells staining with $\mathrm{F} 4 / 80$ at $24 \mathrm{~h}$ after ICH was increased in all hippocampi compared to the 4 -h time point $(p<0.05)$. Furthermore, F4/80-positive cells at $24 \mathrm{~h}$ were significantly reduced in bilateral hippocampi of mice receiving nesiritide compared to the same hippocampi of mice receiving saline (ipsilateral hippocampus: $7.13 \pm 0.85$ versus $11.5 \pm 1.46$ cells $/ 10^{6} \mu \mathrm{m}^{3}$ for ICH + BNP versus ICH + saline, respectively [ $p<0.05]$; contralateral hippocampus: $3.48 \pm 0.43$ versus $7.25 \pm 0.53$ cells $/ 10^{6} \mu \mathrm{m}^{3}$ for ICH $+\mathrm{BNP}$ versus $\mathrm{ICH}+$ saline, respectively $[p<0.01]$; Fig. 8).

To determine if increases in inflammatory cytokines and microglial activation were ultimately related to neuronal degeneration, we performed immunohistochemistry with Fluoro-Jade B, which identifies dead and injured neurons, at 


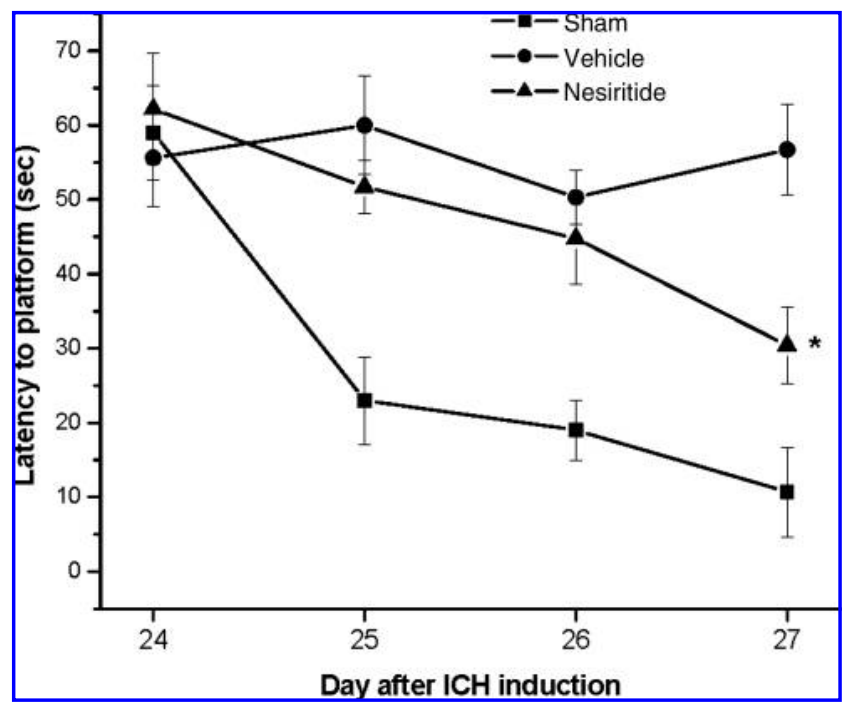

FIG. 5. Morris water maze latencies over consecutive days after intracerebral hemorrhage (ICH) (post-injury days 24$28)$ in mice given nesiritide $(8 \mu \mathrm{g} / \mathrm{kg})$ or saline by tail vein injection at $30 \mathrm{~min}$ and $4 \mathrm{~h}$ after injury. Mice given $8 \mu \mathrm{g} / \mathrm{kg}$ nesiritide demonstrated significantly shorter latencies and faster learning over the 4 days of testing, regardless of injury mechanism $\left({ }^{*} p<0.05\right.$ nesiritide versus saline).

$24 \mathrm{~h}$ after $\mathrm{ICH}$ in mice that received nesiritide $(8 \mu \mathrm{g} / \mathrm{kg})$ or saline injection $30 \mathrm{~min}$ and $4 \mathrm{~h}$ after $\mathrm{ICH}(n=5 /$ group). We found a significant reduction in Fluoro-Jade B-positive neurons in the contralateral hippocampus of mice receiving ne-

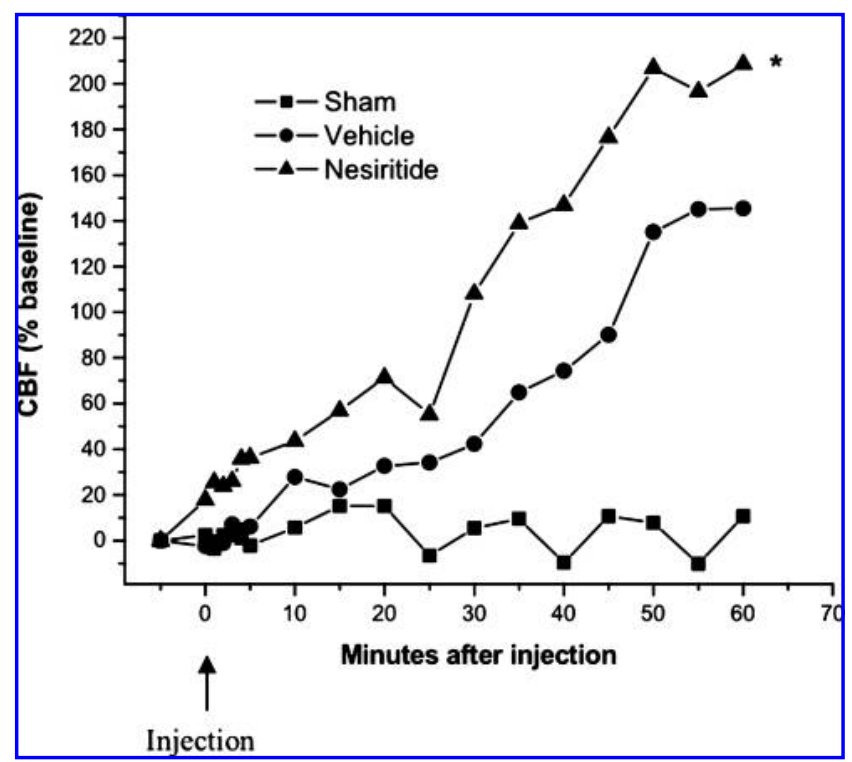

FIG. 6. Laser doppler cerebral blood flow (CBF) study over the left middle cerebral artery distribution from 25-60 min after TBI in mice either given nesiritide $(8 \mu \mathrm{g} / \mathrm{kg})$ or saline by tail vein injection at $30 \mathrm{~min}$ after injury or untreated after injury. Mice given nesiritide demonstrated a significant increase in CBF over the $60 \mathrm{~min}$ of monitoring $\left({ }^{*} p<0.05\right.$ nesiritide versus saline). Of note, all mice demonstrated a nearly $50 \%$ initial reduction of $\mathrm{CBF}$ compared to uninjured animals, and in nesiritide-treated animals, the CBF returned to near normal levels within $60 \mathrm{~min}$ after treatment.

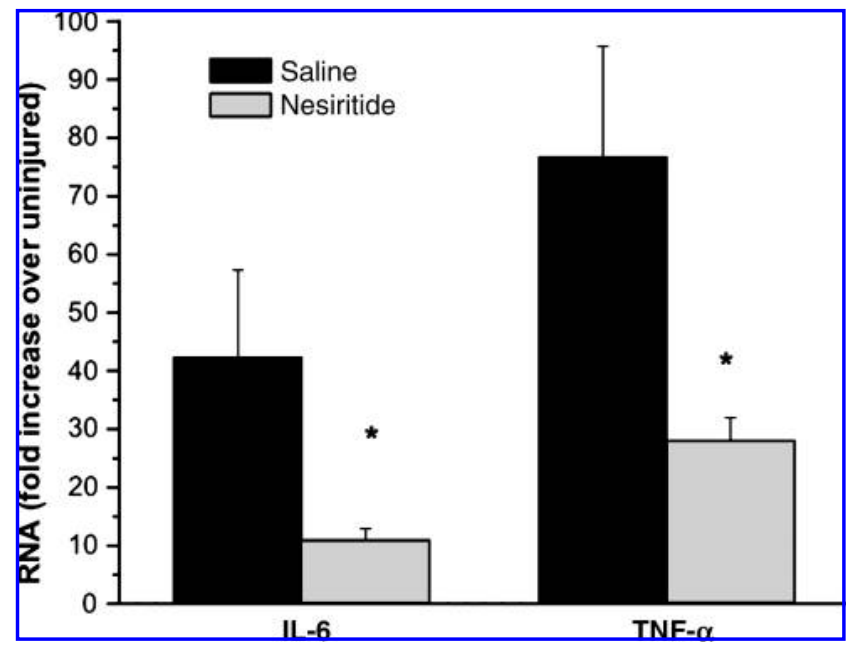

FIG. 7. mRNA polymerase chain reaction for tumor necrosis factor- $\alpha$ (TNF- $\alpha$ ) and interleukin-6 (IL-6) levels at $4 \mathrm{~h}$ after intracerebral hemorrhage in mice given nesiritide $(8 \mu \mathrm{g} / \mathrm{kg})$ or saline by tail vein injection at $30 \mathrm{~min}$ and $4 \mathrm{~h}$ after injury. Mice given nesiritide demonstrated a significant decrease in the mRNA fold change for both proteins $\left({ }^{*} p<0.05\right)$.

siritide compared to those receiving saline $(24.25 \pm 6.05$ versus $108 \pm 32.34$ cells $/ 10^{6} \mu \mathrm{m}^{3}$ for $\mathrm{ICH}+\mathrm{BNP}$ versus $\mathrm{ICH}+$ saline, respectively [ $p<00.5]$; Fig. 9).

\section{Discussion}

In the current study, we demonstrate that administration of exogenous human recombinant BNP (nesiritide) improves functional outcome and reduces histological evidence of neuronal injury in murine models of TBI and ICH. These neuroprotective effects were associated with an augmentation of $\mathrm{CBF}$ and reduced neuroinflammatory responses, suggesting that nesiritide may represent a viable, novel therapeutic strategy. Nesiritide was approved by the FDA in 2001 for the treatment of congestive heart failure, and has pluripotent properties in advanced heart failure, including lowering left ventricular filling pressures, neurohormonal effects, enhanced post-injury ventricular remodeling, and improved cardiac myocyte relaxation (Burger et al., 2002; Clarkson et al., 1995; Publication Committee for the VMAC Investigators, 2002; Sakata et al., 2001; Tamura et al., 2000; Yancy et al., 2004).

Although initially identified in the porcine brain, BNP is found primarily in the heart, and is a clinically useful marker of left ventricular distension in the setting of congestive heart failure. Furthermore, multiple studies have demonstrated that BNP is elevated following ischemic stroke and TBI, even in the absence of cardiac injury. In addition, elevations in natriuretic peptides such as BNP have been linked to cerebral salt-wasting syndromes following TBI ( $\mathrm{Lu}$ et al., 2008), and subarachnoid hemorrhage (McGirt et al., 2004). However, the consistent finding that BNP is elevated after diverse forms of acute CNS injury (including trauma, ICH, and stroke), and that its upregulation in the CSF is independent of changes in serum sodium or cardiac pathology, suggest that BNP may also play an adaptive role in the injured CNS (Kirchhoff et al., 2006; Powner et al., 2007). 

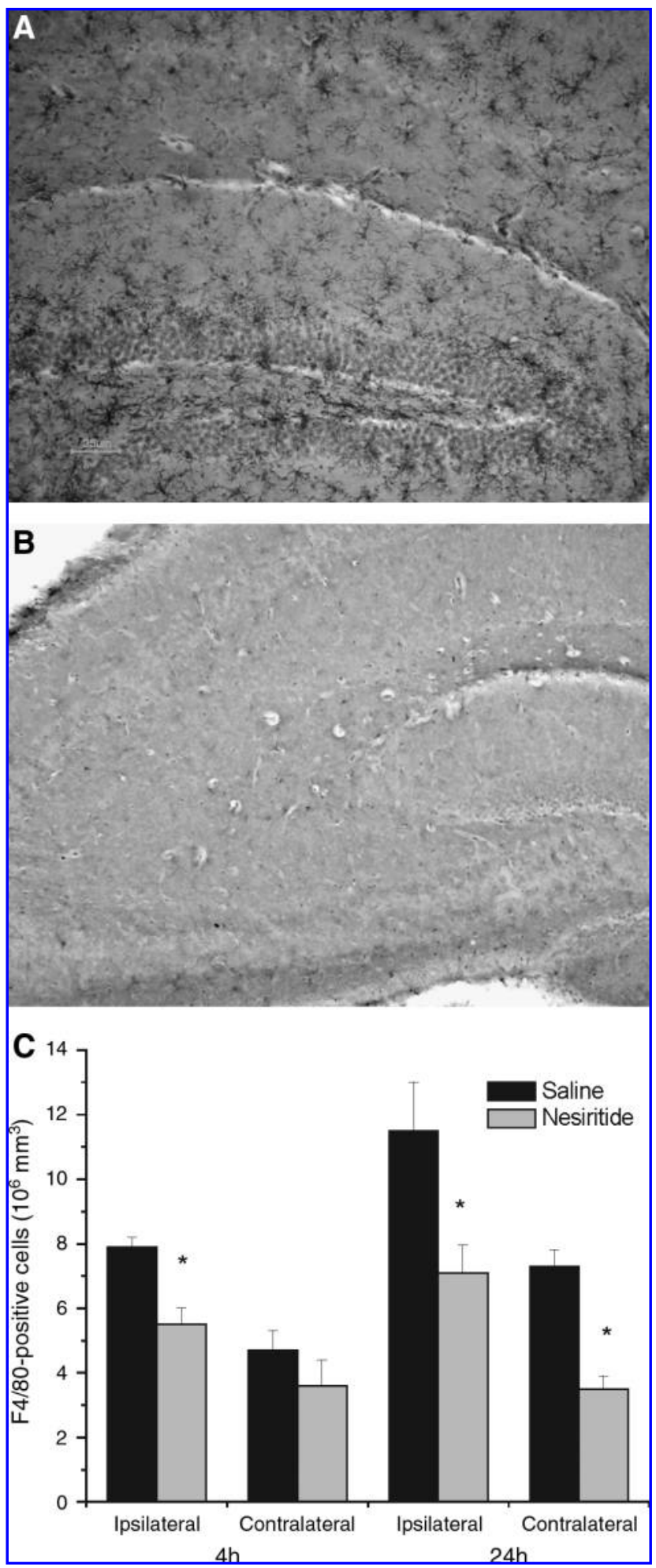

FIG. 8. F4/80 staining for hippocampal microglial cells at $24 \mathrm{~h}$ after intracerebral hemorrhage in mice receiving $(\mathbf{A})$ saline or (B) nesiritide $(8 \mu \mathrm{g} / \mathrm{kg})$ by tail vein injection at $30 \mathrm{~min}$ and $4 \mathrm{~h}$ after injury. Although some initial microgliosis was seen at $4 \mathrm{~h}$, an overall increase was seen in bilateral hippocampi at $24 \mathrm{~h}$ (only negligible F4/80 staining was seen in uninjured mice). Additionally, mice given $8 \mu \mathrm{g} / \mathrm{kg}$ nesiritide demonstrated a significant decrease in the number of cells staining with F4/80 in bilateral hippocampi at $24 \mathrm{~h}$, the ipsilateral hippocampus at $4 \mathrm{~h}$ post-injury, and bilateral hippocampi at $24 \mathrm{~h}\left(\mathbf{C}^{*}{ }^{*} p<0.05\right)$.
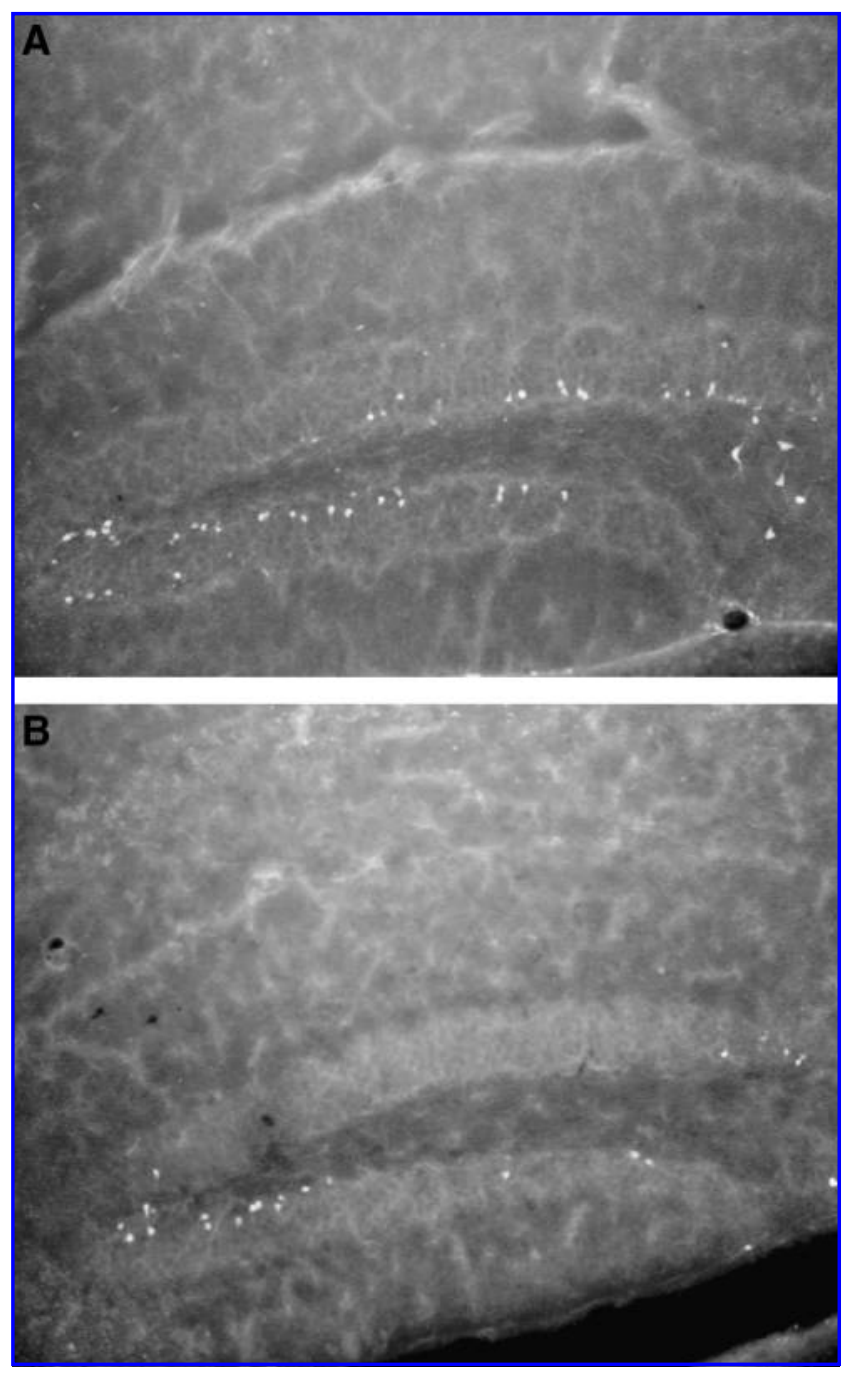

FIG. 9. Fluoro-Jade B staining for neuronal dengeneration at $4 \mathrm{~h}$ after intracerebral hemorrhage (ICH) in the hippocampi of mice receiving (A) saline or (B) nesiritide $(8 \mu \mathrm{g} / \mathrm{kg})$ by tail vein injection at $30 \mathrm{~min}$ and $4 \mathrm{~h}$ after injury. Mice given nesiritide demonstrated a significant decrease in the number of cells staining with Fluoro-Jade B in the contralateral hippocampus $(p<0.05)$. Bilateral hippocampal injury represents a fundamental alteration in the pathophysiology of the mechanisms of injury seen after $\mathrm{ICH}$.

One mechanism by which BNP may exert beneficial effects after acute brain injury is by augmenting CBF. This is especially true in the setting of TBI, where post-traumatic cerebral hypoperfusion has been linked to an exacerbation of brain injury (Hlatky et al., 2003), through impairment of autoregulation (i.e., the ability of an organ to maintain constant tissue blood flow despite changes in perfusion pressure), and an inability of pial arterioles to respond to normal changes in $\mathrm{PaCO}_{2}$ and $\mathrm{PaO}_{2}$ (Wei et al., 1980). Interestingly, in mice injured with $\mathrm{ICH}$, though there was a profound decrease in $\mathrm{CBF}$ by laser doppler flowmetry, we did not demonstrate any difference in CBF with nesiritide treatment, despite finding an improvement in outcome. Presumably this is due to the lack of the existence of a perihematomal penumbra in this disease state (Fainardi et al., 2008; Orakcioglu et al., 2008), but may 
also be related to the doppler probe being unable to differentiating between hematoma and brain parenchyma.

Although the exact mechanisms by which BNP modulates CBF have not been described, it is known to modulate systemic blood pressure, blood flow to other vital organs (kidneys) and the sympathetic nervous system, and perhaps most interestingly, the renin-angiotensin system (McGrath et al., 2005). In the brain, angiotensin appears to cause receptormediated vasoconstriction, among diverse other effects (Saavedra, 2005). By inhibiting this effect, BNP may allow an overall increase in CBF when the angiotensin system is upregulated after injury. Increasing evidence suggests that the renin-angiotensin system plays a role in neuronal injury after ischemia, and the modification of this system may result in improved cerebrovascular physiology and improved neurological outcomes (Ito et al., 2001, 2002). Moreover, it appears that modulation of the renin-angiotensin system itself may confer some level of neuroprotection after cerebral ischemia, beyond the modulation of blood flow (Zhou et al., 2005).

In addition to any direct effects on CBF, BNP may also improve outcomes by modulating neuroinflammatory responses, as is more likely the case in ICH. Acute CNS injury is associated with microglial and astrocytic activation, as well as the release of reactive oxygen species and inflammatory mediators. In particular, proinflammatory cytokines such as IL-6 and TNF- $\alpha$ have been suggested to play an important role in early events mediating blood-brain barrier breakdown and subsequent development of cerebral edema (Ramilo et al., 1990). Multiple studies have demonstrated that elevated levels of inflammatory cytokines, such as TNF- $\alpha$ and IL-6, predict secondary brain injury and poor long-term outcome after TBI (Minambres et al., 2003; Woiciechowsky et al., 2002). Consistent with prior work (James et al., 2008a; Wang et al., 2007a), we found robust upregulation of TNF- $\alpha$ and IL-6 RNA in injured brain, which was attenuated by treatment with nesiritide. This was associated with a concurrent reduction in the number of F4/80-positive microglia and Fluoro-Jade B-positive neurons in bilateral hippocampi following injury, as well improved short- and long-term neurological outcomes. Although these effects are consistent with prior data demonstrating that natriuretic peptides may oppose inflammation (Konig et al., 2007; Ma et al., 2004; Meirovich et al., 2008; Vesely and de Bold, 2009), there are few data on its role in the human brain.

Finally, it is interesting that despite improving CBF and attenuating cytokines, an increase in eNOS transcription was not demonstrated. Because cerebrovascular tone and blood flow are mediated in part by eNOS (Morikawa et al., 1994; Yamada et al., 2000), the beneficial effects of BNP agonists on post-traumatic cerebral perfusion could be due to upregulation of eNOS; however, there are several mechanisms by which BNP may enhance eNOS activity without affecting RNA levels (Yemisci et al., 2008). As an example, HMG-CoA reductase inhibitors (statins) have been demonstrated to enhance eNOS activity acutely through post-translational modification, increasing NO generation by enhancing phosphorylation of eNOS by the protein kinase Akt, but not affecting mRNA levels (Luo et al., 2000). Our results are also consistent with a report by Kureishi and colleagues (Kureishi et al., 2000), who found that statins could produce a very rapid improvement in endothelial function that is independent of changes in eNOS mRNA levels via similar pathways.
Although not the main hypothesis of this study, we found neurocognitive effects after ICH in mice as evidenced by impaired performance on the MWM. These cognitive deficits were associated with histological evidence of hippocampal injury. Unlike TBI, in which cognitive deficits are well described, ICH is traditionally thought of as a local phenomenon. Our findings of microgliosis and neuronal injury in the contralateral hemisphere, and hippocampal pathology in areas remote from the hemorrhagic lesion, are consistent with recent articles demonstrating contralateral hemispheric changes and injury after ICH in pre-clinical models (MunBryce et al., 2004, 2006; Nguyen et al., 2008); however, we could find no published data directly addressing the issue of long-term neurocognitive changes after primary $\mathrm{ICH}$ in humans. In light of these findings and the evolving understanding of the mechanisms of secondary injury following hematoma formation, it is reasonable to assume that similar impairments might exist in clinical populations.

Several limitations of this study should be addressed. First, augmentation of CBF by administration of BNP may only partially explain its neuroprotective effects. It is likely that BNP exerts additional effects, resulting in decreased recruitment of hematogenous monocytes and activation of endogenous microglia. The exact mechanisms by which this occurs remain to be elucidated. Although both TBI and ICH may have common pathways of glial activation, cerebral edema, and secondary neuronal injury, it would be important to define the patient population for whom administration of BNP might be most appropriate. Given the association with adverse effects such as renal injury, careful determination of the likelihood of these adverse consequences in patients with acute CNS injury is required. For example, the antihypertensive effect of BNP analogues may be more appropriate in the setting of $\mathrm{ICH}$, where patients are often hypertensive and blood pressure control is a priority. Finally, the dose of nesiritide utilized in this study is well above that currently approved by the FDA for use in humans. Thus a full doseresponse curve will need to be determined prior to any attempts at translating our findings into the clinical arena.

Despite these limitations, our results suggest that BNP may play a protective role in the setting of acute brain injury, and thus may represent a novel therapeutic strategy. In our preclinical paradigms of TBI and ICH, administration of exogenous BNP was well tolerated and associated with durable functional and histological improvements. Although our data suggest that the benefit of nesiritide may be in part mediated by its vasoactive and anti-inflammatory properties, further studies are needed to fully elucidate its mechanism of action and to determine its therapeutic potential for acute CNS injury.

\section{Acknowledgments}

This study was made possible through funding from the FAER Mentored Research Training Grant (M.L.J.).

\section{Author Disclosure Statement}

No competing financial interests exist.

\section{References}

Brosnan, M.J., Clark, J.S., Jeffs, B., Negrin, C.D., Van Vooren, P., Arribas, S.M., Carswell, H., Aitman, T.J., Szpirer, C., Macrae, 
I.M., and Dominiczak, A.F. (1999). Genes encoding atrial and brain natriuretic peptides as candidates for sensitivity to brain ischemia in stroke-prone hypertensive rats. Hypertension 33, 290-297.

Burger, A.J., Horton, D.P., LeJemtel, T., Ghali, J.K., Torre, G., Dennish, G., Koren, M., Dinerman, J., Silver, M., Cheng, M.L., and Elkayam, U. (2002). Effect of nesiritide (B-type natriuretic peptide) and dobutamine on ventricular arrhythmias in the treatment of patients with acutely decompensated congestive heart failure: the PRECEDENT study. Am. Heart J. 144, 11021108.

Clarkson, P.B., Wheeldon, N.M., Macleod, C., Coutie, W., and MacDonald, T.M. (1995). Brain natriuretic peptide: effect on left ventricular filling patterns in healthy subjects. Clin. Sci. (Lond.) 88, 159-164.

Di Angelantonio, E., De Castro, S., Toni, D., Sacchetti, M.L., Biraschi, F., Prencipe, M., and Fiorelli, M. (2007). Determinants of plasma levels of brain natriuretic peptide after acute ischemic stroke or TIA. J. Neurol. Sci. 260, 139-142.

Fainardi, E., Borrelli, M., Saletti, A., Schivalocchi, R., Azzini, C., Cavallo, M., Ceruti, S., Tamarozzi, R., and Chieregato, A. (2008). CT perfusion mapping of hemodynamic disturbances associated to acute spontaneous intracerebral hemorrhage. Neuroradiology 50, 729-740.

Foda, M.A., and Marmarou, A. (1994). A new model of diffuse brain injury in rats. Part II: Morphological characterization. J. Neurosurg. 80, 301-313.

Hamm, R.J., Pike, B.R., O'Dell, D.M., Lyeth, B.G., and Jenkins, L.W (1994) The rotarod test: an evaluation of its effectiveness in assessing motor deficits following traumatic brain injury. J. Neurotrauma 11, 187-196.

Hlatky, R., Lui, H., Cherian, L., Goodman, J.C., O’Brien, W.E., Contant, C.F., Robertson, C.S. (2003). The role of endothelial nitric oxide synthase in the cerebral hemodynamics after controlled cortical impact injury in mice. J. Neurotrauma 20, 995-1006.

Holscher, C. (1999). Stress impairs performance in spatial water maze learning tasks. Behav. Brain Res. 100, 225-235.

Ito, T., Nishimura, Y., and Saavedra, J. (2001). Pre-treatment with candesartan protects from cerebral ischaemia. J. Renin Angiotensin Aldosterone Syst. 2, 174-179.

Ito, T., Yamakawa, H., Bregonzio, C., Terron, J.A., Falcon-Neri, A., and Saavedra, J.M. (2002). Protection against ischemia and improvement of cerebral blood flow in genetically hypertensive rats by chronic pretreatment with an angiotensin II AT1 antagonist. Stroke 33, 2297-2303.

James, M.L., Sullivan, P.M., Lascola, C.D., Vitek, M.P., and Laskowitz, D.T. (2008a). Pharmacogenomic effects of apolipoprotein e on intracerebral hemorrhage. Stroke 40, 632-639.

James, M.L., Warner, D.S., and Laskowitz, D.T. (2008b). Preclinical models of intracerebral hemorrhage: a translational perspective. Neurocrit. Care 9, 139-152.

Jensen, J.K., Mickley, H., Bak, S., Korsholm, L., and Kristensen, S.R. (2006). Serial measurements of N-terminal pro-brain natriuretic peptide after acute ischemic stroke. Cerebrovasc. Dis. 22, 439-444.

Kasama, S., Toyama, T., Kumakura, H., Takayama, Y., Ishikawa, T., Ichikawa, S., Suzuki, T., and Kurabayashi, M. (2004). Effects of intravenous atrial natriuretic peptide on cardiac sympathetic nerve activity in patients with decompensated congestive heart failure. J. Nucl. Med. 45, 1108-1113.

Kirchhoff, C., Stegmaier, J., Bogner, V., Buhmann, S., Mussack, T., Kreimeier, U., Mutschler, W., and Biberthaler, P. (2006). Intrathecal and systemic concentration of NT-proBNP in pa- tients with severe traumatic brain injury. J. Neurotrauma 23 , 943-949.

Konig, D., Neubauer, O., Nics, L., Kern, N., Berg, A., Bisse, E., and Wagner, K.H. (2007). Biomarkers of exercise-induced myocardial stress in relation to inflammatory and oxidative stress. Exerc. Immunol. Rev. 13, 15-36.

Kureishi, Y., Luo, Z., Shiojima, I., Bialik, A., Fulton, D., Lefer, D.J., Sessa, W.C., and Walsh, K. (2000). The HMG-CoA reductase inhibitor simvastatin activates the protein kinase Akt and promotes angiogenesis in normocholesterolemic animals. Nat. Med. 6, 1004-1010.

Laskowitz, D.T., Kasner, S.E., Saver, J., Remmel, K.S., and Jauch, E.C. (2009). Clinical usefulness of a biomarker-based diagnostic test for acute stroke: the Biomarker Rapid Assessment in Ischemic Injury (BRAIN) study. Stroke 40, 77-85.

Livak, K.J., and Schmittgen, T.D. (2001). Analysis of relative gene expression data using real-time quantitative PCR and the 2(-Delta Delta C(T)) method. Methods 25, 402-408.

Lu, D.C., Binder, D.K., Chien, B., Maisel, A., and Manley, G.T. (2008). Cerebral salt wasting and elevated brain natriuretic peptide levels after traumatic brain injury: 2 case reports. Surg. Neurol. 69, 226-229.

Luchner, A., and Schunkert, H. (2004). Interactions between the sympathetic nervous system and the cardiac natriuretic peptide system. Cardiovasc. Res. 63, 443-449.

Luo, Z., Fujio, Y., Kureishi, Y., Rudic, R.D., Daumerie, G., Fulton, D., Sessa, W.C., and Walsh, K. (2000). Acute modulation of endothelial Akt/PKB activity alters nitric oxide-dependent vasomotor activity in vivo. J. Clin. Invest. 106, 493-499.

Lynch, J.R., Wang, H., Mace, B., Leinenweber, S., Warner, D.S., Bennett, E.R., Vitek, M.P., McKenna, S., and Laskowitz, D.T. (2005). A novel therapeutic derived from apolipoprotein E reduces brain inflammation and improves outcome after closed head injury. Exp. Neurol. 192, 109-116.

Ma, K.K., Ogawa, T., and de Bold, A.J. (2004). Selective upregulation of cardiac brain natriuretic peptide at the transcriptional and translational levels by pro-inflammatory cytokines and by conditioned medium derived from mixed lymphocyte reactions via p38 MAP kinase. J. Mol. Cell Cardiol. 36, 505-513.

McGirt, M.J., Blessing, R., Nimjee, S.M., Friedman, A.H., Alexander, M.J., Laskowitz, D.T., and Lynch, J.R. (2004). Correlation of serum brain natriuretic peptide with hyponatremia and delayed ischemic neurological deficits after subarachnoid hemorrhage. Neurosurgery 54, 1369-1373; discussion 73-74.

McGrath, M.F., de Bold, M.L., and de Bold, A.J. (2005). The endocrine function of the heart. Trends Endocrinol. Metab. 16, 469-477.

Meirovich, Y.F., Veinot, J.P., de Bold, M.L., Haddad, H., Davies, R.A., Masters, R.G., Hendry, P.J., and de Bold, A.J. (2008). Relationship between natriuretic peptides and inflammation: proteomic evidence obtained during acute cellular cardiac allograft rejection in humans. J. Heart Lung Transplant. 27, 31-37.

Minambres, E., Cemborain, A., Sanchez-Velasco, P., Gandarillas, M., Diaz-Reganon, G., Sanchez-Gonzalez, U., and LeyvaCobian, F. (2003) Correlation between transcranial interleukin-6 gradient and outcome in patients with acute brain injury. $\underline{\text { Crit. }}$ Care Med. 31, 933-938.

Modrego, P.J., Boned, B., Berlanga, J.J., and Serrano, M. (2008). Plasmatic B-type natriuretic peptide and C-reactive protein in hyperacute stroke as markers of CT-evidence of brain edema. Int. J. Med. Sci. 5, 18-23.

Montaner, J., Perea-Gainza, M., Delgado, P., Ribo, M., Chacon, P., Rosell, A., Quintana, M., Palacios, M.E., Molina, C.A., and 
Alvarez-Sabin, J. (2008). Etiologic diagnosis of ischemic stroke subtypes with plasma biomarkers. Stroke 39, 22802287.

Morikawa, E., Moskowitz, M.A., Huang, Z., Yoshida, T., Irikura, K., and Dalkara, T. (1994). L-arginine infusion promotes nitric oxide-dependent vasodilation, increases regional cerebral blood flow, and reduces infarction volume in the rat. Stroke 25, 429-435.

Morris, R. (1984). Developments of a water-maze procedure for studying spatial learning in the rat. J. Neurosci. Methods 11, 47-60.

Mukoyama, M., Nakao, K., Hosoda, K., Suga, S., Saito, Y., Ogawa, Y., Shirakami, G., Jougasaki, M., Obata, K., Yasue, H., et al. (1991). Brain natriuretic peptide as a novel cardiac hormone in humans. Evidence for an exquisite dual natriuretic peptide system, atrial natriuretic peptide and brain natriuretic peptide. J. Clin. Invest. 87, 1402-1412.

Mun-Bryce, S., Roberts, L., Bartolo, A., and Okada, Y. (2006). Transhemispheric depolarizations persist in the intracerebral hemorrhage swine brain following corpus callosal transection. Brain Res. 1073-1074, 481-490.

Mun-Bryce, S., Roberts, L.J., Hunt, W.C., Bartolo, A., and Okada, Y. (2004). Acute changes in cortical excitability in the cortex contralateral to focal intracerebral hemorrhage in the swine. Brain Res. 1026, 218-226.

Nakagawa, K., Yamaguchi, T., Seida, M., Yamada, S., Imae, S., Tanaka, Y., Yamamoto, K., and Ohno, K. (2005). Plasma concentrations of brain natriuretic peptide in patients with acute ischemic stroke. Cerebrovasc. Dis. 19, 157-164.

Nguyen, A.P., Huynh, H.D., Sjovold, S.B., and Colbourne, F. (2008). Progressive brain damage and alterations in dendritic arborization after collagenase-induced intracerebral hemorrhage in rats. Curr. Neurovasc. Res. 5, 171-177.

Orakcioglu, B., Becker, K., Sakowitz, O.W., Herweh, C., Kohrmann, M., Huttner, H.B., Steiner, T., Unterberg, A., and Schellinger, P.D. (2008). MRI of the perihemorrhagic zone in a rat ICH model: effect of hematoma evacuation. Neurocrit. Care 8, 448-455.

Powner, D.J., Hergenroeder, G.W., Awili, M., Atik, M.A., and Robertson, C. (2007). Hyponatremia and comparison of NTpro-BNP concentrations in blood samples from jugular bulb and arterial sites after traumatic brain injury in adults: a pilot study. Neurocrit. Care 7, 119-123.

Publication Committee for the VMAC Investigators (Vasodilation in the Management of Acute CHF). (2002). Intravenous nesiritide vs. nitroglycerin for treatment of decompensated congestive heart failure: a randomized controlled trial. IAMA 287, 1531-1540.

Ramilo, O., Saez-Llorens, X., Mertsola, J., Jafari, H., Olsen, K.D., Hansen, E.J., Yoshinaga, M., Ohkawara, S., Nariuchi, H., and McCracken, G.H., Jr. (1990). Tumor necrosis factor alpha/ cachectin and interleukin 1 beta initiate meningeal inflammation. J. Exp. Med. 172, 497-507.

Rosenberg, G.A., Estrada, E., Wesley, M., and Kyner, W.T. (1990). Autoradiographic patterns of brain interstitial fluid flow after collagenase-induced haemorrhage in rat. Acta Neurochir. Suppl. (Wien.) 51, 280-282.

Rubattu, S., Sciarretta, S., Valenti, V., Stanzione, R., and Volpe, M. (2008). Natriuretic peptides: an update on bioactivity, potential therapeutic use, and implication in cardiovascular diseases. Am. J. Hypertens. 21, 733-741.

Saavedra, J.M. (2005). Brain angiotensin II: new developments, unanswered questions and therapeutic opportunities. Cell Mol. Neurobiol. 25, 485-512.
Sakata, Y., Yamamoto, K., Masuyama, T., Mano, T., Nishikawa, N., Kuzuya, T., Miwa, T., and Hori, M. (2001). Ventricular production of natriuretic peptides and ventricular structural remodeling in hypertensive heart failure. J. Hypertens. 19, 1905-1912.

Schmued, L.C., and Hopkins, K.J. (2000). Fluoro-Jade B: a high affinity fluorescent marker for the localization of neuronal degeneration. Brain Res. 874, 123-130.

Sudoh, T., Kangawa, K., Minamino, N., and Matsuo, H. (1988). A new natriuretic peptide in porcine brain. Nature 332, 78-81.

Sviri, G.E., Soustiel, J.F., and Zaaroor, M. (2006). Alteration in brain natriuretic peptide (BNP) plasma concentration following severe traumatic brain injury. Acta Neurochir. (Wien.) 148, 529-533; discussion 33.

Tamura, N., Ogawa, Y., Chusho, H., Nakamura, K., Nakao, K., Suda, M., Kasahara, M., Hashimoto, R., Katsuura, G., Mukoyama, M., Itoh, H., Saito, Y., Tanaka, I., Otani, H., and Katsuki, M. (2000). Cardiac fibrosis in mice lacking brain natriuretic peptide. Proc. Natl. Acad. Sci. U.S.A. 97, 4239-4244.

Tsuchiya, D., Hong, S., Kayama, T., Panter, S.S., and Weinstein, P.R. (2003). Effect of suture size and carotid clip application upon blood flow and infarct volume after permanent and temporary middle cerebral artery occlusion in mice. Brain Res. 970, 131-139.

Vesely, D.L., and de Bold, A.J. (2009). Cardiac natriuretic peptides gene expression and secretion in inflammation. J. Investig. Med. 57, 29-32.

Wang, H., Durham, L., Dawson, H., Song, P., Warner, D.S., Sullivan, P.M., Vitek, M.P., and Laskowitz, D.T. (2007a). An apolipoprotein E-based therapeutic improves outcome and reduces Alzheimer's disease pathology following closed head injury: evidence of pharmacogenomic interaction. Neuroscience 144, 1324-1333.

Wang, H., Lynch, J.R., Song, P., Yang, H.J., Yates, R.B., Mace, B., Warner, D.S., Guyton, J.R., and Laskowitz, D.T. (2007b). Simvastatin and atorvastatin improve behavioral outcome, reduce hippocampal degeneration, and improve cerebral blood flow after experimental traumatic brain injury. Exp. Neurol. 206, 59-69.

Wei, E.P., Dietrich, W.D., Povlishock, J.T., Navari, R.M., and Kontos, H.A. (1980). Functional, morphological, and metabolic abnormalities of the cerebral microcirculation after concussive brain injury in cats. Circ. Res. 46, 37-47.

West, M.J., Ostergaard, K., Andreassen, O.A., and Finsen, B. (1996). Estimation of the number of somatostatin neurons in the striatum: an in situ hybridization study using the optical fractionator method. J. Comp. Neurol. 370, 11-22.

West, M.J., Slomianka, L., and Gundersen, H.J. (1991). Unbiased stereological estimation of the total number of neurons in the subdivisions of the rat hippocampus using the optical fractionator. Anat. Rec. 231, 482-497.

Woiciechowsky, C., Schoning, B., Cobanov, J., Lanksch, W.R., Volk, H.D., and Docke, W.D. (2002). Early IL-6 plasma concentrations correlate with severity of brain injury and pneumonia in brain-injured patients. J. Trauma 52, 339-435.

Yamada, M., Huang, Z., Dalkara, T., Endres, M., Laufs, U., Waeber, C., Huang, P.L., Liao, J.K., and Moskowitz, M.A. (2000). Endothelial nitric oxide synthase-dependent cerebral blood flow augmentation by L-arginine after chronic statin treatment. J. Cereb. Blood Flow Metab. 20, 709-717.

Yancy, C.W., Saltzberg, M.T., Berkowitz, R.L., Bertolet, B., Vijayaraghavan, K., Burnham, K., Oren, R.M., Walker, K., Horton, D.P., and Silver, M.A. (2004). Safety and feasibility of using serial infusions of nesiritide for heart failure in an 
outpatient setting (from the FUSION I trial). Am. J. Cardiol. 94 , 595-601.

Yemisci, M., Ay, H., Kocaefe, C., Qui, J., Topalkara, K., Ozguc, M., Kirazli, S., Ozcebe, O., Moskowitz, M.A., and Dalkara, T. (2008). Statin potentiates human platelet eNOS activity without enhancing eNOS mRNA and protein levels. Cerebrovasc. Dis. 26, 190-198.

Zhou, J., Ando, H., Macova, M., Dou, J., and Saavedra, J.M. (2005). Angiotensin II AT1 receptor blockade abolishes brain microvascular inflammation and heat shock protein responses in hypertensive rats. J. Cereb. Blood Flow Metab. 25, 878-886.

Address correspondence to: Michael L. James, M.D. Duke University Medical Center 3094

Durham, NC 27710

E-mail: james040@mc.duke.edu 


\section{This article has been cited by:}

1. Wei Sun, Amanda Peacock, Jane Becker, Barbara Phillips-Bute, Daniel T. Laskowitz, Michael L. James. 2012. Correlation of leukocytosis with early neurological deterioration following supratentorial intracerebral hemorrhage. Journal of Clinical Neuroscience 19:8, 1096-1100. [CrossRef]

2. Michael L. James, Haichen Wang, Viviana Cantillana, Beilei Lei, Dawn N. Kernagis, Hana N. Dawson, Lori D. Klaman, Daniel T. Laskowitz. 2012. TT-301 Inhibits Microglial Activation and Improves Outcome after Central Nervous System Injury in Adult Mice. Anesthesiology 116:6, 1299-1311. [CrossRef]

3. Daniel T. Laskowitz, Beilei Lei, Hana N. Dawson, Haichen Wang, Steven T. Bellows, Dale J. Christensen, Michael P. Vitek, Michael L. James. 2011. The apoE-mimetic Peptide, COG1410, Improves Functional Recovery in a Murine Model of Intracerebral Hemorrhage. Neurocritical Care . [CrossRef]

4. Paula Pifarre, Judith Prado, María Antonia Baltrons, Merce Giralt, Pere Gabarro, Douglas L. Feinstein, Juan Hidalgo, Agustina Garcia. 2011. Sildenafil (Viagra) ameliorates clinical symptoms and neuropathology in a mouse model of multiple sclerosis. Acta Neuropathologica 121:4, 499-508. [CrossRef]

5. Ingo Schulz, Claudia Engel, Andre J Niestroj, Ulrike Zeitschel, Katja Menge, Astrid Kehlen, Antje Meyer, Steffen Rossner, Hans-Ulrich Demuth. 2011. Heteroarylketones inhibit astroglial interleukin-6 expression via a STAT3/NF-kappaB signaling pathway. Journal of Neuroinflammation 8:1, 86. [CrossRef] 